\title{
RELIGIOUS SITES AND
}

SACRED SPACES IN LITHUANIA

\section{AND POLAND: A COMPARISON} BETWEEN THE ŠILUVA COMPLEX AND THE ŚWIEBODZIN STATUE OF JESUS ${ }^{1}$

\section{Robert Parkin}

School of Anthropology and Museum Ethnography, Oxford, United Kingdom e-mail: robert.parkin@anthro.ox.ac.uk

\begin{abstract}
This paper compares two religious sites associated with the Catholic Church: Šiluva in Lithuania, where a religious complex has existed for several centuries because of visions of the Virgin Mary seen there in 1608; and the much more recent statue of Jesus Christ erected earlier this century in the town of Świebodzin in western Poland. It is argued that, unlike the former, a central site where religious devotion comes together with expressions of Lithuanian nationhood, the latter's status as a religious site is still uncertain and at best in a process of becoming. This is not least because this site appears to lend itself to touristic interest more than religious devotion expressed through pilgrimage. It therefore raises questions about what we mean by sacred spaces in a way the site at Šiluva does not.
\end{abstract}

Keywords: pilgrimage, Šiluva, statues of Christ, Świebodzin, tourism 
Statues of Jesus Christ are exceedingly common around the world, and some of them are large in scale. Since 2010, to the latter must be added the statue in the west Polish town of Swiebodzin, which rivals the more famous one in Rio de Janeiro, Brazil, in size and form. Unlike the Rio statue, which depicts Christ as the Redeemer, the one in Świebodzin is crowned, in conformity with the image of Christ as king. In respect of its size, it is in definite rivalry with its Rio opposite number, and the dimensions themselves have symbolic significance. Thus the statue itself is 33 metres high, one metre for every year of Christ's life, and the crown measures three metres in height, one for every year of Christ's ministry.

In this article, I compare this site with another I am familiar with, though much less so, namely the religious complex at Šiluva in Lithuania, which I visited in 2014. This site has grown up on the basis of a vision of the Virgin Mary dating back to 1608; thus it is some four centuries older than the site in Swiebodzin, which in addition is not based on any sort of miracle, though it has acquired miracles associated with it subsequent to its planning and execution. The purpose of this comparison is therefore to reflect on the popularity of sacred sites and the reasons for people visiting them. In particular, are visitors to the new statue to be regarded as pilgrims, or as tourists, or as both? Is the distinction between them, which the sociologist Erik Cohen (1922) sees as very clear on the basis that the pilgrim's destination is an aspect of his or her own culture, the tourist's destination the culture of others, still valid?

In fact, the statue was, in one view, the vanity project of a local priest, Sylwester Zawadzki, ${ }^{2}$ who had a reputation for building and restoring ecclesiastical buildings, with which the statue can be associated (as such, he was known as the 'Builder Priest'). There are different reports of how Zawadzki came to build the statue just here, in this small and unremarkable town in western Poland. In one version, he was inspired by Christ coming to him in a dream. A second version tells how he took over an earlier plan to build such a statue in the eastern Polish town of Tarnów, which came to nothing. Finally, there was his own desire to build a church in a local parish that lacked one. He did indeed build a new church to serve the new post-war housing estates to the south of the town centre. In this version, the idea for the statue, which is located in the same parish, came subsequently.

At all events, between about 2005 and 2010 Zawadzki's life was dominated by this project, which involved overcoming both bureaucratic hurdles and 
difficulties in construction. By all accounts it was done on the cheap, partly through willing donations, partly allegedly by Zawadzki exploiting the goodwill of those involved in the construction by treating work done as donations that need not be paid for and/or as voluntary labour. As a result, the site still has an unfinished air, and the statue itself has had to be worked on further to improve its facilities and even its basic stability since being consecrated in 2010 .

Local opinion is not universally in favour of the statue, nor of Zawadzki, whose non-celibate, self-indulgent lifestyle became notorious and offended many. For many, especially the non-religious, his statue is an expensive indulgence, the costs of which could have been spent more usefully on other local projects. However, others, especially the more religious-minded (including a local doctor), have supported the idea and think that the fuss made about him and the statue is unnecessary. The Catholic Church's attitude to the statue has also been ambivalent. While not obstructing Zawadzki's initiative directly, its support was evidently lukewarm throughout, though local Church dignitaries did play a full role in its eventual consecration, and some individuals were more supportive than others. However, the statue has not been adopted by the Church as a major site of pilgrimage like other sites in Poland (such as Częstochowa or Góra Świętej Anny/St. Anne's Hill in Silesia) or Lithuania next door (such as Šiluva, the Hill of Crosses or Tytuvenai; on the first of these, see below). Against this, Zawadzki did gather around him a hard core of lay supporters who remain faithful to his memory to this day and are still involved in managing and improving the site of his statue.

Despite these controversies, which are largely only of local importance, the statue has become a site of tourism, with a steady stream of visitors walking round it base (it sits on a mound providing a view of the surrounding area, which is on the outskirts of the town) and using its other facilities, such as the café, shop and toilets. There are also some religious facilities, such as an openair pew for prayer and a structure consisting of electronic candles that light up when a coin is inserted into it, but comparatively few visitors make use of either. Clearly some visitors have already visited Zawadzki's new church nearby and carried out their devotions there, but others, especially if from Germany and other foreign (especially non-Catholic countries), appear to be tourists to the statue alone. No doubt some treat their visit as a pilgrimage, especially indicated by the occasional infirm visitor who prays at the open-air pew, but in the main they seem to be in the minority. 


\section{Robert Parkin}

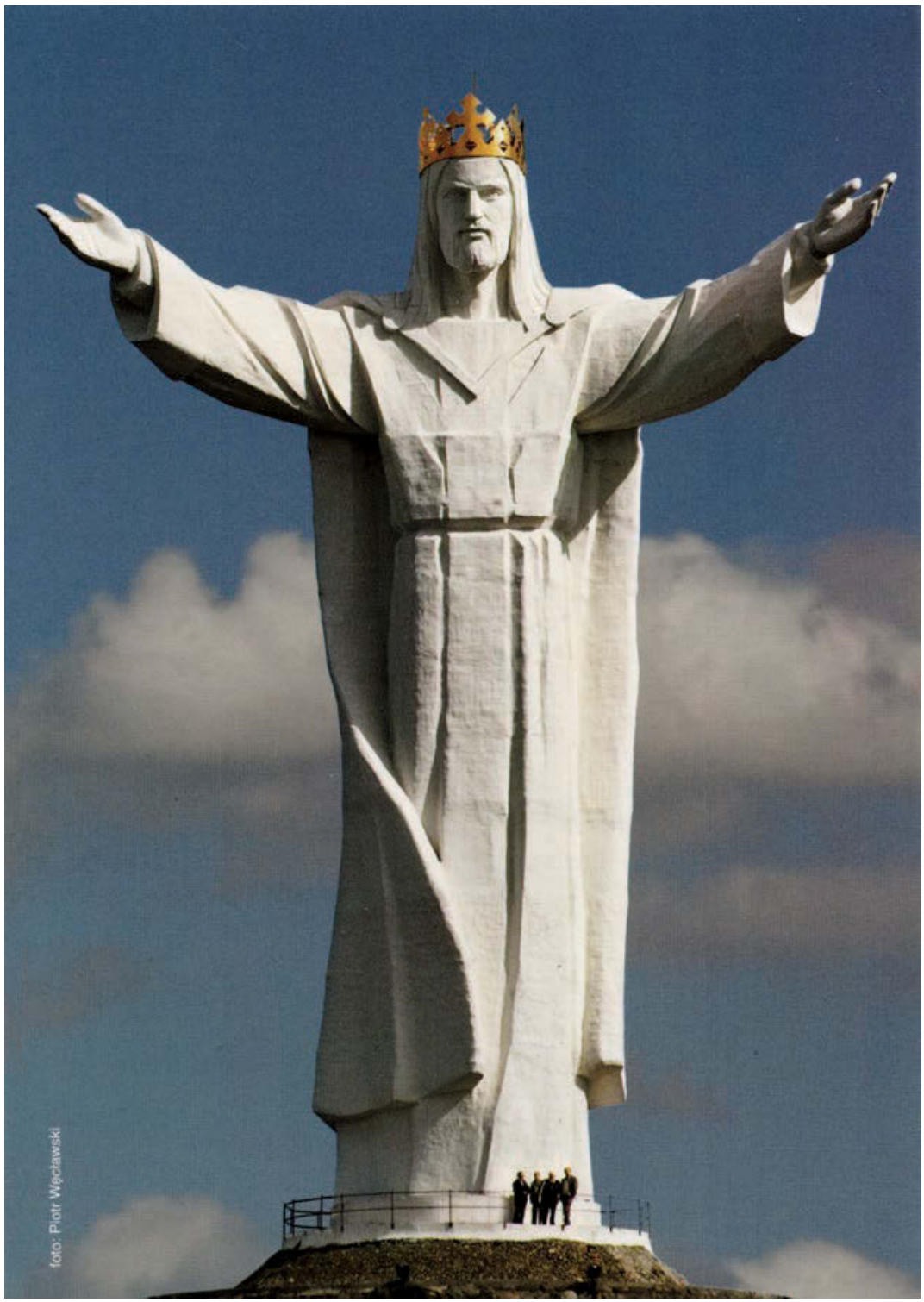

The Świebodzin statue of Christ. Photo by Robert Parkin. 
There are nonetheless some miracles associated with the site, all of which are connected with Zawadzki himself to a greater or lesser extent. Thus even in the planning stage, while Zawadzki was hospitalized briefly with exhaustion, doubting that his statue would ever be built, a figure in white appeared to him to tell him that all would be well - and shortly afterwards, much to his delight, the local authorities gave him formal permission. A second miracle is connected with the removal - very probably illegally - of Zawadzki's heart after his death in 2014 and its internment near the base of the statue, in accordance with his last wishes; i.e. his heart had been in the project metaphorically, so it ought to be there literally. Although it was raining during the brief ceremony connected with its deposition, a dry area appeared around those celebrating the event, protecting them from the wet. Lastly Zawadzki is said to have died at three o'clock in the afternoon, supposedly the time of Christ's death on the cross. However, all these miracles were ancillary to the statue and the circumstances of its construction - two of them were subsequent to its construction - and none of them provide the inspiration for the statue being constructed in the first place, nor do they appear to be what draws visitors to the site, since they are little known and are certainly not emphasized by the Church authorities.

The Świebodzin statue therefore raises important issues about what is meant by both sacred spaces and sacred objects. Associated with this, we have become used to the blurring of the distinction between pilgrimage and tourism, given the use of touristic methods and paraphernalia by pilgrims. This is seen in the forms of modern travel like buses (though many pilgrims also walk, even on their knees, as at Tytuvenai in Lithuania) the provision of accommodation, of souvenirs, etc. Nonetheless there is a definite sense, from observation and some discreet enquiries, that tourism is more important than pilgrimage where visitors to the statue are concerned. As for the statue itself, is it just an object, a representation of Christ, or does it actually contain his sacredness? Again, the answer will probably depend on whether the visitor regards him- or herself as a pilgrim or a tourist. Those who pray at the site, we can be a little more sure, at least regard it as a sacred space and, as such see the statue itself as containing Christ's sacredness, at least in part.

Nonetheless there is a definite sense in which the site of the Swiebodzin statue is defective as a sacred space, a point that will hopefully emerge more fully by means of a brief comparison. 
Compared with Šiluva in Lithuania, a small village where a large pilgrimage complex consisting of a basilica, chapel and seminary has grown up around the site of a vision of the Virgin Mary in 1608 and is attended by thousands of pilgrims every September, including the president and the rest of the political class, ${ }^{3}$ the attention devoted to the Świebodzin statue is modest indeed. One key difference is the much greater length of time the site at Šiluva has been in existence - since at least the seventeenth century, as opposed to a mere decade or so - and the fact that accordingly it has acquired symbolic significance as the site not just of a vision of the Virgin, ${ }^{4}$ but also of the fate of the Lithuanian nation and its resistance to outside rule, especially in the Soviet period. Thus, as well as being an 'exclusive spiritual centre' and a site of pilgrimage, it is now also 'a place of national unity' (Račiūnaite-Paužuolienè 2009: 156); in the words of Stankevičienè (2009: 34), 'an ordinary place [in] Lithuania became a special spiritual centre'. Also, the site was heavily patronized by the Catholic Church in the seventeenth century, after being taken back from Protestant control in 1622 (Kamuntavičienè 2009: 17-18), and the local priesthood and bishops were behind the construction of the main basilica in the succeeding century (Šinkūnaitè 2009; Stankevičienè 2009: 21).

By contrast, and as already noted, while in Świebodzin the local church hierarchy ultimately supported Zawadzki's initiatives in the sense of taking part in the consecration of both church and statue, they have not adopted the site of the latter as a sacred space of any great importance - nor was Zawadzki promoted within the Church for his efforts, but remained an ordinary parish priest until his death. In other words, while any statue of Jesus is bound to have a sacred aura for the believer, as a sacred space this particular site lacks the necessary associations with divine interventions or other sacred events - miracles, in short - that would attract the interest of both the church hierarchy and believers in such miracles. To repeat, as a sacred space it has its own miracles, but in this case they did not stimulate the idea for the statue but evolved after its conceptualization. Only time will tell whether the site will become anymore sacred because it has the statue.

Nevertheless, in so far as the Church supported it at all, it can be seen as a small example of the attempts being made by the Catholic Church in Poland to maintain its position in a time of a moderate decline in church attendance and indeed to advance its cause in general, along with the activities of, for example, the strongly Catholic and conservative Radio Marya and associated media, 
as well as Poles' continued devotion to John Paul II's memory as the Polish pope and the Church's tendency to align itself politically with the right-wing Law and Justice Party ${ }^{5}$ government that came to power in 2015. Moreover, the statue and the new church in whose parish it sits can both be associated with recent suggestions that Christ should be declared the King of Poland and the Virgin Mary the Queen of Poland. On 21 November 2000, again on Zawadzki's initiative (publicity material), Swiebodzin submitted itself symbolically to the protection of Christ the King, and the consecration of the statue, which was to symbolize this submission in concrete form, took place exactly ten years later. Indeed, one other sacred item placed next to the pew by the statue is the enthronement prayer, and as already noted the statue wears a crown to symbolize Christ as king. ${ }^{6}$ Generally these suggestions seem to have come from enthusiastic individuals rather than the Church hierarchy, with whom the submission of Świebodzin to Christ the King was unpopular. Nonetheless, if in a much more modest and controversial fashion, they do represent attempts to link the Catholic Church to the Polish nation in a manner that can certainly be compared with the much more central place of the site of Šiluva in Lithuania's sense of nationhood. The key difference here is that in the Polish case these moves have been bottom-up initiatives not fully adopted by either Church or state; in the case of Šiluva, Church and state come together every September (the latter in the form of visits by the entire political class from the president downwards) to celebrate Lithuanian nationhood as a secular phenomenon deeply rooted in the Church's validation of it. This is not to say that the Polish state ignores or is hostile to the Catholicism of a majority of its citizens - far from it; rather, this extraordinary monument to Christ the King has so far not interested the religious authorities and secular politicians in the country as a site at which they might come together to affirm their joint commitment to the maintenance of Polish Catholic society and Polish nationhood.

In short, to repeat, the Świebodzin statue raises the issue of what constitutes a sacred space and whether such spaces are any different from a simple site of commemoration. While the new church, the Sanctuarium, like any consecrated church, is sacred in the sense that one encounters, indeed seeks out, the divine there, there is ambiguity over whether this applies to the statue, given its evident attraction for larger numbers of tourists than pilgrims.

Is the same true of other statues of Christ around the world? The circumstances in and reasons for which these other statues have been erected are very 
varied, as are those who sponsored them. Some of them, like the statue of Christ the Redeemer in Rio, have chapels nearby in which services can be held; that is not true of the Swiebodzin statue, which merely has its one outside pew for private prayer. However, the Rio statue had an unambiguously religious motive for its construction in the belief of those behind it that Brazilians were becoming less religious. In many cases, including that of Rio, the inspiration for the statue seems to have come from a lay believer or organization rather than a priest, often as a way of honouring Christ, or indeed someone or something entirely different, rather than marking the site of a vision or other miracle. Sometimes, indeed, the religious message seems to be entirely absent or secondary, political reasons being to the fore. Thus the statue of Christ in Dili, East Timor, was given to the then Indonesian territory by President Suharto of Indonesia to mark twenty years of its incorporation into Indonesia, simultaneously acknowledging the territory's Christian heritage; the statue in the Andes was put up by laity in 1904 to celebrate Chile and Argentina having resolved a potentially dangerous border dispute two years earlier (Bowman 1915: 76); the statue in Lima, Peru, was motivated by the desire of some Brazilian businessmen to celebrate Alan Garcia's presidency; a bishop of Ibiza constructed a statue to thank those on the island who had hidden him in the Spanish Civil War; the statue in Lisbon was put up to keep Portugal out of WWII; that in Madeira marks the place where the bodies of non-Catholics were disposed of; and in a number of other cases, local businessmen have been prompted to sponsor a statue by community spirit rather than clear religious feeling. ${ }^{7}$ In only one case I know of, apart from the Świebodzin example, was the sponsor motivated by a dream, and that was a businessman in Imo State, Nigeria. ${ }^{8}$ A general question therefore poses itself, namely which comes first in creating a sacred space - a miracle or vision, or a statue or similar structure? 


\section{Notes}

1 This article was originally given as a paper at the International Conference on "History, Religion, and Culture III", held at the Lithuanian Institute of History, Vilnius, Lithuania, on 9-11 October 2017. I am grateful to the organizers for inviting me to the conference.

2 As Zawadzki died in 2014, I feel free to identify him by name, and indeed it would pointless not to, given his reputation and the extensive local knowledge of his activities; his name will forever be linked with his statue, the crowning achievement of his career as the Builder Priest.

3 Personal field observations. I am grateful to Dr Rasa Račiūnaitė-Paužuolienė for facilitating this visit in September 2014.

4 Although there are images of Christ here, in what is a far more complex religious site, the predominant representation appears to be of the Virgin, in accordance with her having appeared here in visions. A number of her images are also crowned; see Stankevičienè 2009.

5 PiS, or Prawa i Sprawiedliwość.

6 The crown is a "royal" one and not the crown of thorns usually associated with Christ's suffering, as in images of the Sacred Heart.

7 Information from Wikipedia, unless otherwise stated.

8 "Africa's largest statue of Jesus unveiled in Imo, the man behind it", The News (Nigeria), 01.01.2016, retrieved 26.04.2016.

\section{References}

Bowman, Isaiah 1915. South America: a geography reader. Chicago: Rand McNally.

Cohen, Erik 1992. Pilgrimage and tourism: convergence and divergence. In: Alan Morinis (ed.) Sacred journeys: the anthropology of pilgrimage. Westport $\mathrm{CO}$ and London: Greenwood Press, pp. 47-61.

Gancewski, Kazimierz 2013. Świebodzin: ludzie, budowle, anegdoty - obrazki z życia codziennego miasta w II połowie XX w. [Świebodzin: People, Buildings, Anecdotes - Images of the Daily Life of the Town in the Second Half of the Twentieth Century]. Świebodzin: Muzeum Regionale w Świebodzinie, pp. 51-56.

Kamuntavičienė, Vaida 2009. Šiluvos parapija XVII a. [Šiluva Parish in the $17^{\text {th }}$ Century]. Meno istorija ir kritika, No. 5, pp. 9-18. 


\section{Robert Parkin}

Račiūnaitė-Paužuolienė, Rasa 2009. Švč. Mergelès Marijos kultas lietuvių šeimos papročiuose [The Cult of the Blessed Virgin Mary in Lithuanian Family Customs]. Soter, No. 29 (57), pp. 141-156.

Šinkūnaitè, Laima 2009. The basilica of the nativity of the Blessed Virgin Mary in Šiluva: the iconology of art. Meno istorija ir kritika, No. 4, pp. 38-65.

Stankevičiene, Regimanta 2009. The image [of] the Blessed Virgin Mary with the Child of the Šiluva basilica: the problems of the origin, iconographic context and dating. Meno istorija ir kritika, No. 5, pp. 19-37. 